\title{
Projected Changes in Snow Water Equivalent over the Tibetan Plateau under Global Warming of $1.5^{\circ}$ and $2^{\circ} \mathrm{C}$
}

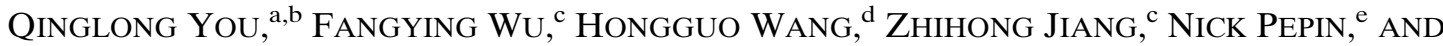 \\ SHICHANG KANG ${ }^{\text {f,g }}$ \\ ${ }^{a}$ Department of Atmospheric and Oceanic Sciences, Institute of Atmospheric Sciences, Fudan University, Shanghai, China \\ ${ }^{\mathrm{b}}$ Innovation Center of Ocean and Atmosphere System, Zhuhai Fudan Innovation Research Institute, Zhuhai, China \\ ${ }^{c}$ Key Laboratory of Meteorological Disaster, Ministry of Education (KLME), Nanjing University of Information Science and \\ Technology, Nanjing, China \\ ${ }^{\mathrm{d}}$ School of Tourism, Shanghai Normal University, Shanghai, China \\ ${ }^{\mathrm{e}}$ Department of Geography, University of Portsmouth, Portsmouth, United Kingdom \\ ${ }^{\mathrm{f}}$ State key laboratory of Cryospheric Science, Northwest Institute of Eco-Environment and Resources, Chinese \\ Academy of Sciences, Lanzhou, China \\ ${ }^{\mathrm{g}}$ CAS Center for Excellence in Tibetan Plateau Earth Sciences, Beijing, China
}

(Manuscript received 27 September 2019, in final form 19 March 2020)

\begin{abstract}
Snow water equivalent (SWE) is a critical parameter for characterizing snowpack, which has a direct influence on the hydrological cycle, especially over high terrain. In this study, SWE from 18 coupled model simulations from phase 5 of the Coupled Model Intercomparison Project (CMIP5) is validated against the Canadian Sea Ice and Snow Evolution Network (CanSISE) SWE. The model simulations under RCP8.5 and RCP4.5 are employed to investigate projected changes in spring/winter SWE over the Tibetan Plateau (TP) under global warming of $1.5^{\circ}$ and $2^{\circ} \mathrm{C}$. Most CMIP5 models overestimate the CanSISE SWE. A decrease in mean spring/winter SWE for both RCPs over most regions of the TP is predicted in the future, with most significant reductions over the western TP, consistent with pronounced warming in that region. This is supported by strong positive correlations between SWE and mean temperature in the future in both seasons. Compared with the preindustrial period, spring/winter SWE over the TP under global warming of $1.5^{\circ}$ and $2^{\circ} \mathrm{C}$ will reduce significantly, at faster rates than over China as a whole and the Northern Hemisphere. SWE changes over the TP do not show a simple elevation dependency under global warming of $1.5^{\circ}$ and $2^{\circ} \mathrm{C}$, with maximum changes in the elevation band of $4000-4500 \mathrm{~m}$. Moreover, there are also strong positive correlations between projected SWE and historical mean SWE, indicating that the initial conditions of SWE are an important parameter of future SWE under specific global warming scenarios.
\end{abstract}

\section{Introduction}

Snow has high reflectance and low thermal conductivity, and when it melts it absorbs latent heat. All these properties are of great importance for surface energy and water budgets, with subsequent impacts on atmospheric circulation on global and regional scales (Barnett et al. 1989; Beniston et al. 2018; Bulygina et al. 2011; Hancock et al. 2013; Kang et al. 2019; Tan et al. 2019; Zhang 2005). For example, the snow cover in the Northern Hemisphere has decreased on average by almost $10 \%$ since the 1980s (Brown 2000; Brown and Mote 2009; Dye 2002; Groisman et al. 1994).

Corresponding author: Qinglong You, yqingl@126.com
In recent decades, changes in snow have attracted widespread attention in both scientific and public communities, particularly because this can be a highly visible reflection of climate change. However, snow cover shows large spatial and temporal variabilities and previous studies on different continental and regional scales can come to contrasting conclusions. Examples include studies on the Northern Hemisphere (Brown 2000; Brown and Mote 2009; Hernández-Henríquez et al. 2015; Jeong et al. 2017; Kong and Wang 2017; Shi and Wang 2015; Wang et al. 2018; Zeng et al. 2018), the Eurasian continent (Brown and Derksen 2013; Bulygina et al. 2011; Zhong et al. 2018), the pan-Arctic region (Shi et al. 2011), China (Chen et al. 2016; Ji and Kang 2013; Tan et al. 2019), Xinjiang province and central Asia 
TABLE 1. The CMIP5 models used in this study.

\begin{tabular}{|c|c|c|c|}
\hline No. & Model name & Modeling center (or group) & $\begin{array}{l}\text { Atmospheric } \\
\text { resolution (lon } \times \text { lat) }\end{array}$ \\
\hline 1 & ACCESS1.0 & $\begin{array}{l}\text { Commonwealth Scientific and Industrial Research Organization and Bureau of } \\
\text { Meteorology, Australia }\end{array}$ & $1.875^{\circ} \times 1.25^{\circ}$ \\
\hline 2 & BCC_CSM1.1 & Beijing Climate Center, China Meteorological Administration, China & $2.8125^{\circ} \times 2.8125^{\circ}$ \\
\hline 3 & BNU-ESM & $\begin{array}{l}\text { College of Global Change and Earth System Science, Beijing Normal } \\
\text { University, China }\end{array}$ & $2.8125^{\circ} \times 2.8125^{\circ}$ \\
\hline 4 & CanESM2 & Canadian Centre for Climate Modeling and Analysis, Canada & $2.8125^{\circ} \times 2.8125^{\circ}$ \\
\hline 5 & CCSM4 & National Center for Atmospheric Research, United States & $1.875^{\circ} \times 0.625^{\circ}$ \\
\hline 6 & CESM1(BGC) & Community Earth System Model contributors, United States & $1.875^{\circ} \times 0.625^{\circ}$ \\
\hline 7 & CSIRO-Mk3.6.0 & $\begin{array}{l}\text { Commonwealth Scientific and Industrial Research Organization/Queensland } \\
\text { Climate Change Centre of Excellence, Australia }\end{array}$ & $1.875^{\circ} \times 1.875^{\circ}$ \\
\hline 8 & GFDL CM3 & Geophysical Fluid Dynamics Laboratory, United States & $2.5^{\circ} \times 2^{\circ}$ \\
\hline 9 & GFDL-ESM2G & Geophysical Fluid Dynamics Laboratory, United States & $2.5^{\circ} \times 2^{\circ}$ \\
\hline 10 & GFDL-ESM2M & Geophysical Fluid Dynamics Laboratory, United States & $2.5^{\circ} \times 2^{\circ}$ \\
\hline 11 & INM-CM4 & Institute for Numerical Mathematics, Russia & $2^{\circ} \times 2.5^{\circ}$ \\
\hline 12 & MIROC5 & $\begin{array}{l}\text { National Institute for Environmental Studies, and Japan Agency for Marine-Earth } \\
\text { Science and Technology, Japan }\end{array}$ & $1.4063^{\circ} \times 1.4063^{\circ}$ \\
\hline 13 & MIROC-ESM-CHEM & $\begin{array}{l}\text { National Institute for Environmental Studies, and Japan Agency for Marine-Earth } \\
\text { Science and Technology, Japan }\end{array}$ & $2.8125^{\circ} \times 2.8125^{\circ}$ \\
\hline 14 & MIROC-ESM & $\begin{array}{l}\text { National Institute for Environmental Studies, and Japan Agency for Marine-Earth } \\
\text { Science and Technology, Japan }\end{array}$ & $2.8125^{\circ} \times 2.8125^{\circ}$ \\
\hline 15 & MPI-ESM-LR & Max Planck Institute for Meteorology, Germany & $1.875^{\circ} \times 1.875^{\circ}$ \\
\hline 16 & MPI-ESM-MR & Max Planck Institute for Meteorology, Germany & $1.875^{\circ} \times 1.875^{\circ}$ \\
\hline 17 & MRI-CGCM3 & Meteorological Research Institute, Japan & $1.125^{\circ} \times 1.125^{\circ}$ \\
\hline 18 & NorESM1-M & Norwegian Climate Centre, Norway & $2.5^{\circ} \times 1.875^{\circ}$ \\
\hline
\end{tabular}

(Ke and Liu 2014; Li et al. 2019), the Tibetan Plateau (Li et al. 2018; Qin et al. 2006; Xu et al. 2017; You et al. 2011), Canada (Brown and Goodison 1996; Snauffer et al. 2016), the United States (Dawson et al. 2018; Zeng et al. 2018), Bulgaria (Brown and Petkova 2007), North
America (Ge and Gong 2009), and the Swiss Alps (Laternser and Schneebeli 2003).

Snow water equivalent (SWE) is the amount of water $(\mathrm{mm})$ that would be obtained if the entire snowpack was to be melted. SWE depends on both snow depth and
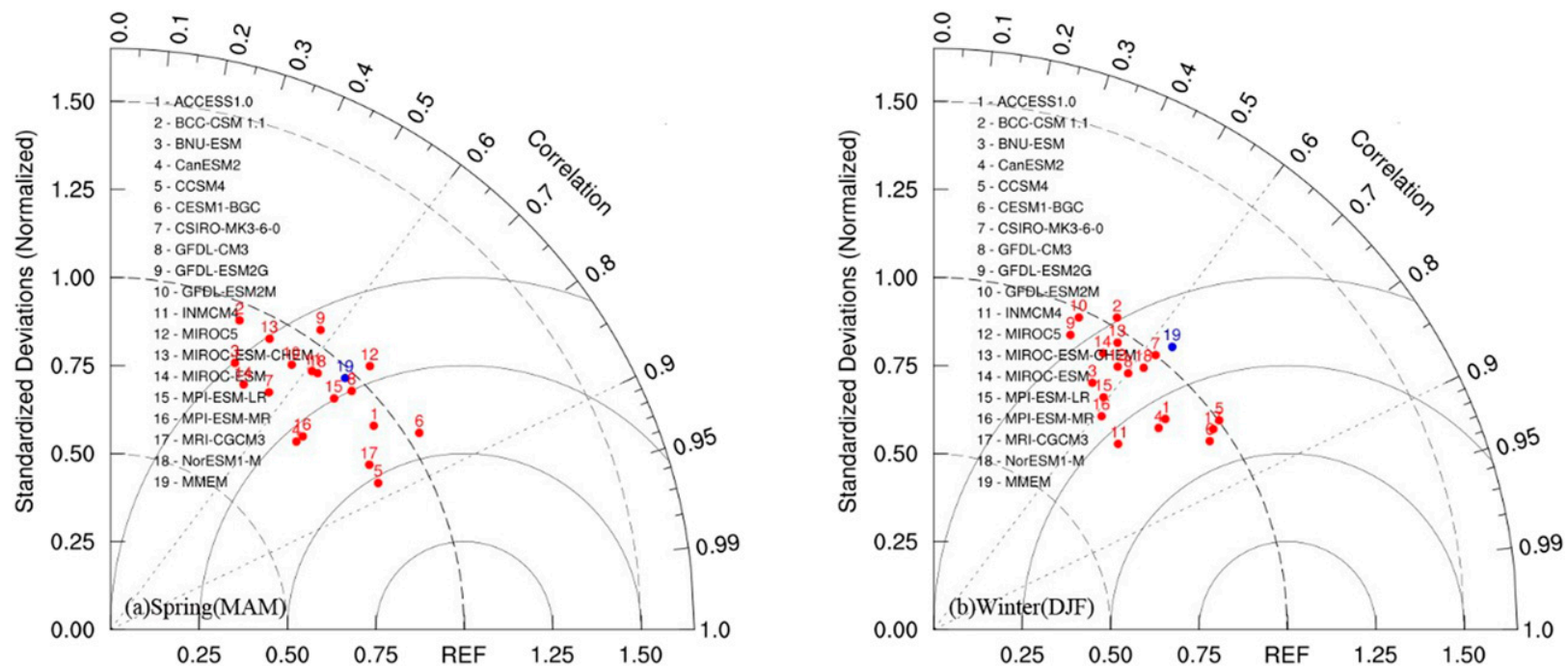

FIG. 1. Taylor diagrams showing correlation coefficients, standard deviation, and root-mean-square difference between observed and simulated mean snow water equivalent (SWE) in (a) spring and (b) winter over the Tibetan Plateau during 1981-2005. The numbers 1-18 refer to the model names in Table 1 . The multimodel ensemble mean (MMEM) refers to a combination of the 18 models listed in Table 1. The REF indicates the CanSISE SWE dataset. The vertical axis indicates the standard deviation ratios, and the numbers along the arc are the spatial correlation. The horizontal axis represents RMSE. 
density, which is a key parameter with direct influence on hydrological cycles (Jeong et al. 2017; Shi and Wang 2015; Zhang and Ma 2018). It has been reported that spring SWE in the Northern Hemisphere has shrunk by 1.6\% per decade during 1967-2012 (IPCC 2013; Jeong et al. 2017). Meanwhile, SWE is projected to decrease by the end of the twenty-first century under representative concentration pathways (RCPs) 8.5, 4.5, and 2.6, and spring SWE has the largest decreases (Shi and Wang 2015). For the most part, SWE is also projected to decrease over lower elevations in North America due to rapid warming and reduced snow season length (Maloney et al. 2014). However, SWE may increase at higher elevations and colder regions of the middle and high latitudes because of increased winter snowfall (Mote et al. 2005; Räisänen 2008; Räisänen and Eklund 2012).

The Tibetan Plateau (TP), with an average elevation of over $4000 \mathrm{~m}$ above mean sea level, is surrounded by even higher mountain ranges (Kang et al. 2010; You et al. 2019). The TP contains the largest cryospheric extent (such as snow, ice, glacier, and permafrost) outside the polar region and mountain snowpack over the TP is a critical source for all the large rivers in Asia, including the Yellow River, Yangtze River, and Yuarlung Zangbo River (Kang et al. 2019, 2010; Yang et al. 2019; Yao et al. 2019; You et al. 2019). Much attention has traditionally been given to study snow characteristics including SWE over the TP, since this is seen as a good indicator of climate change and can influence Asian monsoon systems (Bamzai and Shukla 1999; Ji and Kang 2013; Kang et al. 2010; You et al. 2011, 2020; Zhang and Ma 2018; Zhang et al. 2004; Zhao and Moore 2004). Based on phase 5 of the Coupled Model Intercomparison Project (CMIP5; Taylor et al. 2012), it is found that future warming usually leads to decrease of snow cover, snow depth, and SWE over the TP (IPCC 2013; Ji and Kang 2013; Kong and Wang 2017; Wei and Dong 2015; You et al. 2016). Moreover, SWE over the TP provides an important measure of the availability of water resources, the runoff flow of rivers, and changes in groundwater levels (Kang et al. 2019, 2010; You et al. 2020). However, there are limited studies on future changes of SWE over the TP under specific global warming scenarios of $1.5^{\circ}$ and $2^{\circ} \mathrm{C}$ above preindustrial levels.

In this study, SWE over the TP is studied from the 18 CMIP5 models (Table 1) under global warming of $1.5^{\circ}$ and $2^{\circ} \mathrm{C}$ above preindustrial levels (Moss et al. 2010; Taylor et al. 2012). After describing the datasets and methodological details in section 2, we analyze the fidelity of CMIP5 SWE simulations in section 3a and define the corresponding year over the TP under
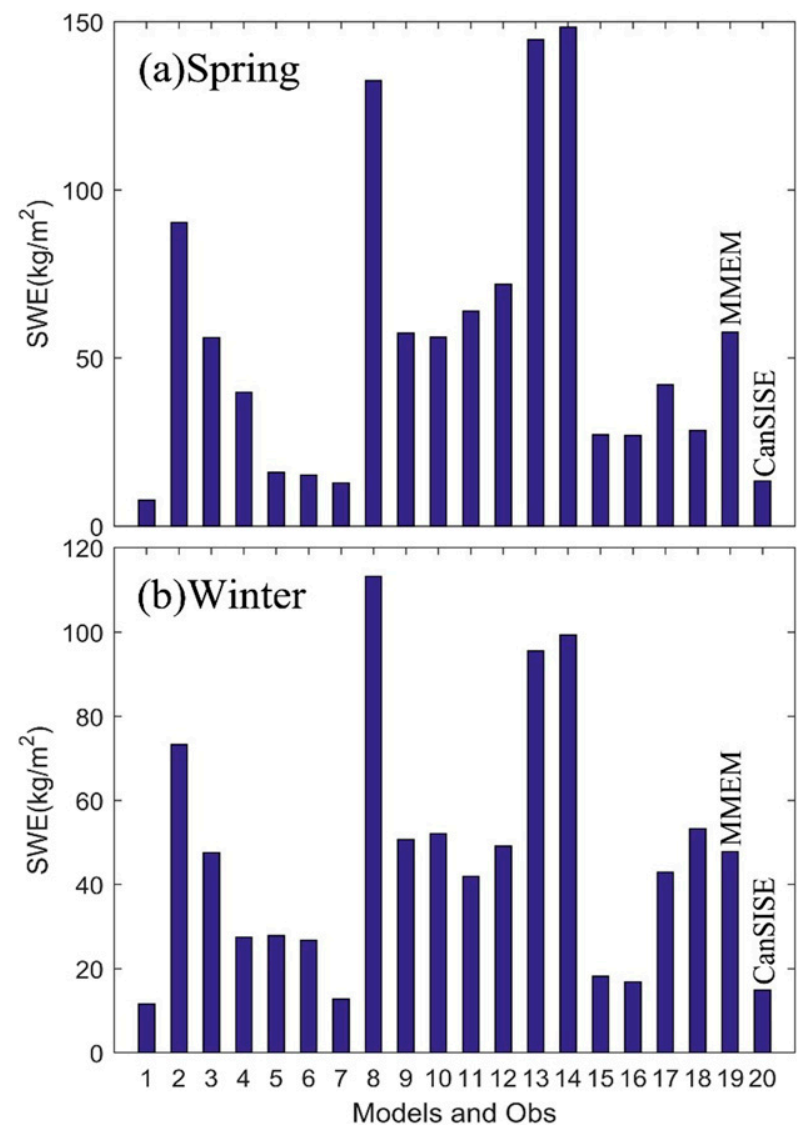

FIG. 2. The average of the observed and simulated mean snow water equivalent (SWE) in (a) spring and (b) winter over the Tibetan Plateau during 1981-2005. Numbers 19 and 20 are the multimodel ensemble mean (MMEM) of the 18 CMIP5 models and the CanSISE SWE dataset, respectively; the others are as in Fig. 1.

global warming of $1.5^{\circ}$ and $2^{\circ} \mathrm{C}$ in section $3 \mathrm{~b}$. In sections $3 \mathrm{c}$ and $3 \mathrm{~d}$, we investigate trends in SWE and the elevation dependency of these changes for the two scenarios. The relationship between SWE and temperature over the TP in the future is also examined in section $3 \mathrm{e}$. A summary with discussion is provided in section 4.

\section{Dataset and method}

\section{a. CMIP5 models}

Monthly SWE from the 18 CMIP5 models under historical and two RCP scenarios (RCP8.5 and RCP4.5) are used (Moss et al. 2010; Taylor et al. 2012). To compare SWE between different CMIP5 models, all CMIP5 simulations are linearly interpolated to a horizontal grid resolution of $1^{\circ} \times 1^{\circ}$ for the winter (DecemberFebruary) and spring (March-May) seasons. Meanwhile, monthly mean, maximum, and minimum temperatures 
TABLE 2. The corresponding year in the 18 CMIP5 models and the multimodel ensemble mean (MMEM) of the 18 CMIP5 models when global mean surface temperature rises by $1.5^{\circ}$ and $2^{\circ} \mathrm{C}$ relative to the preindustrial levels (1850-1900 period) under RCP4.5 and RCP8.5.

\begin{tabular}{lccccc}
\hline \hline & \multicolumn{2}{c}{$1.5^{\circ} \mathrm{C}$} & & \multicolumn{2}{c}{$2^{\circ} \mathrm{C}$} \\
\cline { 2 - 3 } \cline { 5 - 6 } \multicolumn{1}{c}{ Model name } & RCP4.5 & RCP8.5 & & RCP4.5 & RCP8.5 \\
\hline ACCESS1.0 & 2031 & 2026 & & 2051 & 2040 \\
BCC_CSM1.1 & 2024 & 2023 & & 2041 & 2037 \\
BNU-ESM & 2017 & 2016 & & 2026 & 2023 \\
CanESM2 & 2020 & 2015 & & 2031 & 2030 \\
CCSM4 & 2022 & 2019 & & 2040 & 2031 \\
CESM1(BGC) & 2021 & 2017 & & 2043 & 2033 \\
CSIRO-Mk3.6.0 & 2034 & 2030 & & 2049 & 2045 \\
GFDL CM3 & 2033 & 2028 & & 2046 & 2039 \\
GFDL-ESM2G & 2048 & 2034 & & 2072 & 2054 \\
GFDL-ESM2M & 2049 & 2038 & & 2073 & 2053 \\
INM-CM4 & 2056 & 2042 & & 2084 & 2059 \\
MIROC5 & 2051 & 2033 & & 2068 & 2051 \\
MIROC-ESM-CHEM & 2024 & 2019 & & 2038 & 2030 \\
MIROC-ESM & 2021 & 2021 & & 2034 & 2031 \\
MPI-ESM-LR & 2028 & 2020 & & 2045 & 2038 \\
MPI-ESM-MR & 2023 & 2021 & & 2047 & 2040 \\
MRI-CGCM3 & 2053 & 2041 & & 2077 & 2054 \\
NorESM1-M & 2048 & 2033 & 2065 & 2049 \\
MMEM & 2027 & 2025 & 2049 & 2040 \\
\hline
\end{tabular}

from the 18 CMIP5 models are selected in spring and winter over the TP during 2010-2100 under two RCPs.

\section{b. CanSISE SWE dataset}

The fidelity of SWE simulations is evaluated using monthly data from the Canadian Sea Ice and Snow Evolution Network (CanSISE) Observation-Based Ensemble of Northern Hemisphere Terrestrial SWE (Mudryk and Derksen 2017; Mudryk et al. 2015). The CanSISE SWE dataset is composed of five products: 1) GlobSnow retrieved from passive microwave data and weather stations (Takala et al. 2011); 2) ModernEra Retrospective Analysis for Research and Applications data (MERRA) (Rienecker et al. 2011); 3) ECMWF interim reanalysis (ERA-Interim) (Dee et al. 2011); 4) the Crocus snowpack model driven by ERA-Interim (Brun et al. 2013); and 5) the Global Land Data Assimilation System version 2 (GLDAS-2) (Rodell et al. 2004). The final CanSISE SWE dataset (19812010), referred to as observed SWE in this study, is an equally weighted mean of the five datasets (although GlobSnow is not included in mountainous grid cells) and has a spatial resolution of $1^{\circ} \times 1^{\circ}$ (Mudryk and Derksen 2017; Mudryk et al. 2015).

\section{c. Taylor diagrams}

Taylor diagrams are used to show correlation coefficients, standard deviation, and root-mean-square difference
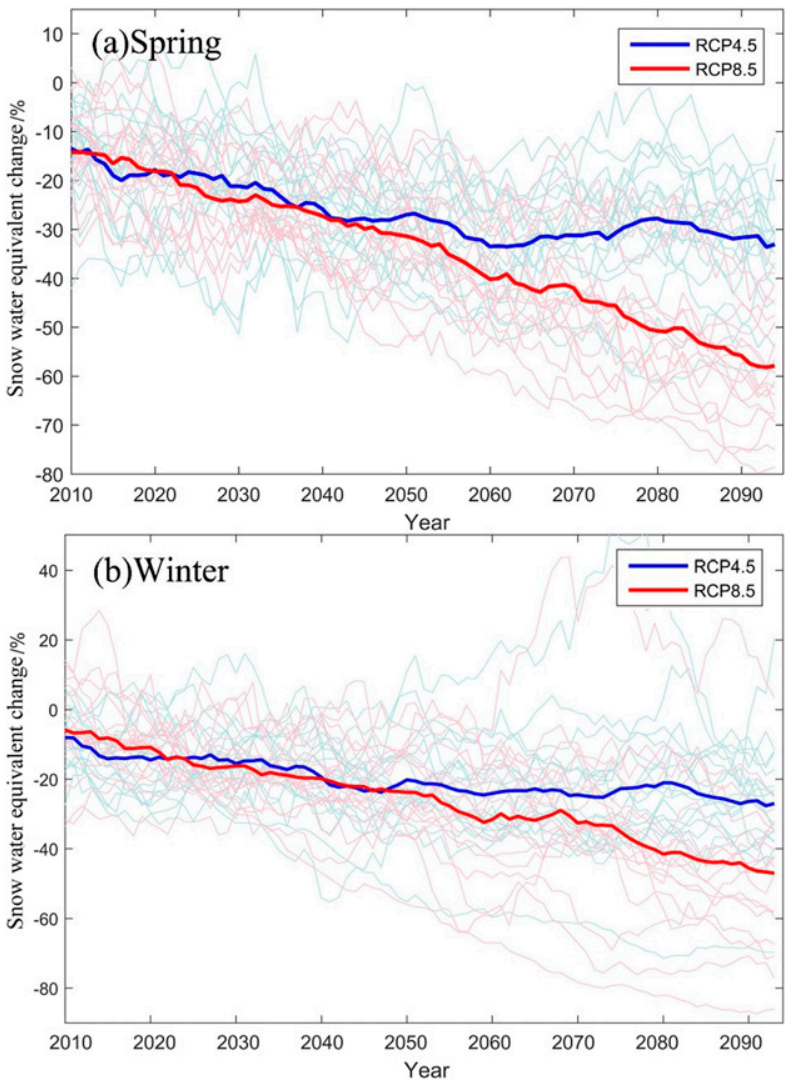

FIG. 3. Projected relative change of regionally averaged snow water equivalent (SWE) (relative to 1850-1900) in (a) spring and (b) winter over the Tibetan Plateau during 2010-2100 under two RCPs from the 18 CMIP5 models and the multimodel ensemble mean (MMEM) of the 18 CMIP5 models listed in Table 1.

between model simulated SWE and observed (CanSISE) SWE in both spring and winter (Taylor 2001).

\section{d. Global warming of $1.5^{\circ}$ and $2^{\circ} \mathrm{C}$}

Global warming of $1.5^{\circ}$ and $2^{\circ} \mathrm{C}$ is defined using the global average surface temperature anomaly based on the multimodel ensemble mean (MMEM) (18 original models). Well-established definitions of $1.5^{\circ}$ and $2^{\circ} \mathrm{C}$ global warming levels are used (King et al. 2017). The $1.5^{\circ} \mathrm{C}$ period (arrival year) is determined to be the time at which the 30 -yr running mean is $1.3^{\circ}-1.7^{\circ} \mathrm{C}$ (crossing the $1.5^{\circ} \mathrm{C}$ global warming level) warmer than the preindustrial period. The $2^{\circ} \mathrm{C}$ period is defined similarly (Wu et al. 2019; Zhang et al. 2019).

\section{Results}

\section{a. Accuracy of CMIP5 SWE simulations}

The accuracy of model-simulated mean SWE in spring/winter in comparison with observed (CanSISE) 


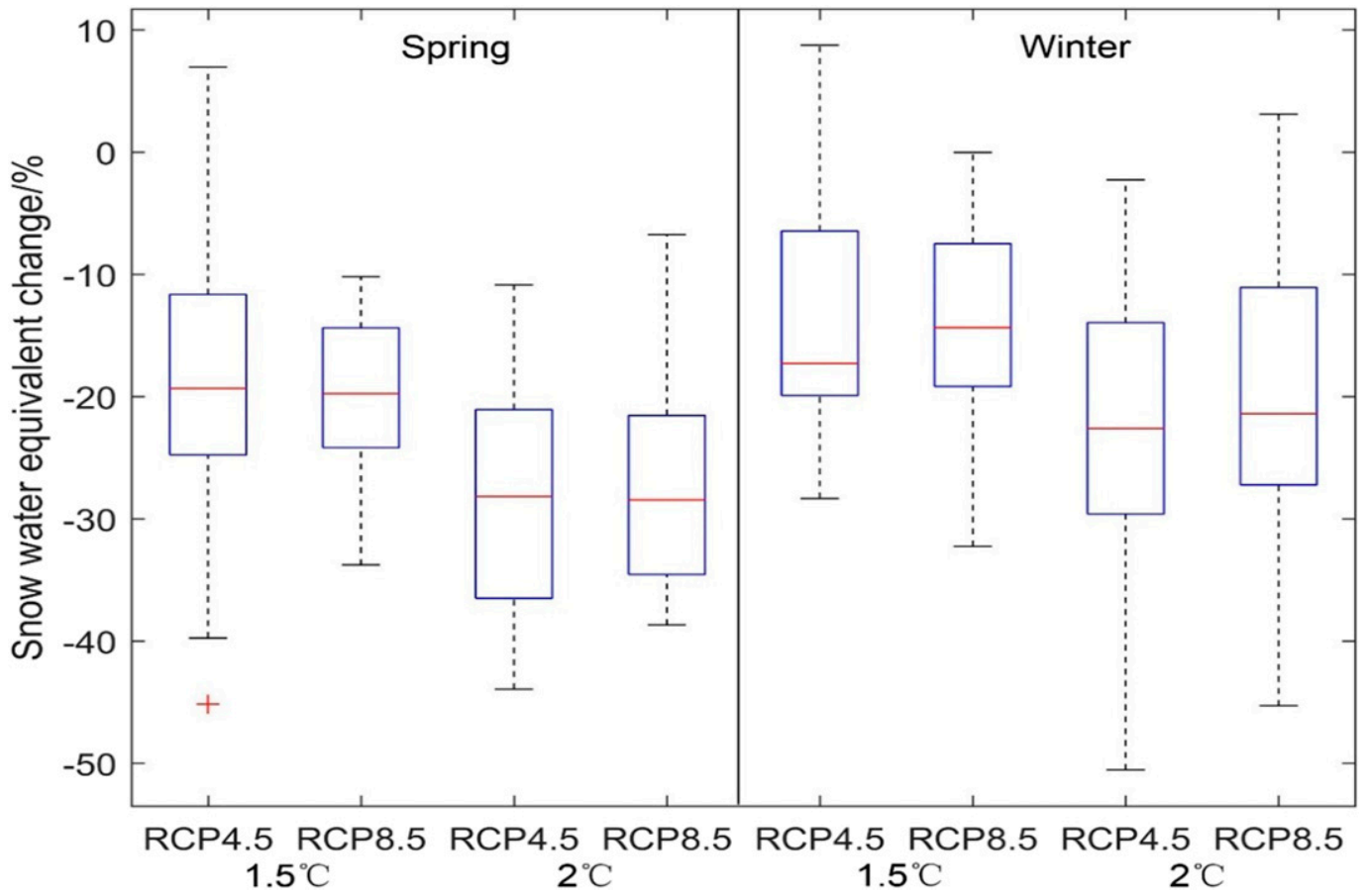

FIG. 4. Boxplots of relative change of regionally averaged snow water equivalent (SWE) relative to the preindustrial levels (1850-1900 period) in (left) spring and (right) winter over the Tibetan Plateau during 2010-2100 under two RCPs from the multimodel ensemble mean (MMEM) of the 18 CMIP5 models listed in Table 1.

SWE is analyzed by constructing a Taylor diagram containing each model during 1981-2005 (Fig. 1). This shows that the CMIP5 models perform relatively well and have higher correlations with CanSISE [e.g., CCSM4, CESM1(BGC), and MRI-CGCM3]. All CMIP5 models exhibit statistically significant correlations with observed SWE but results show a wide range in model performance. The MMEM (number 19 in Fig. 1) provided better agreement than most individual models. During 1981-2005, most CMIP5 models overestimated the CanSISE SWE, and four models (BCC_CSM1.1, GFDL CM3, MIROC-ESM-CHEM, and MIROC-ESM) are particularly poor (Fig. 2). On the other hand, ACCESS1.0, CSIRO-Mk3.6.0, MPI-ESM-LR, and MPI-ESM-MR agree closely with the CanSISE SWE. As a result of a dominance of overestimation in most models, the MMEM is larger than the CanSISE SWE.

\section{b. Estimation of the corresponding year}

Based on the summary of the corresponding year for the 18 CMIP5 models and their MMEM rising by $1.5^{\circ}$ and $2^{\circ} \mathrm{C}$ above preindustrial levels (Table 2), the RCP8.5 scenario results in earlier $1.5^{\circ}$ and $2^{\circ} \mathrm{C}$ warming than $\mathrm{RCP} 4.5$, especially for $2^{\circ} \mathrm{C}$. The RCP4.5 scenario projects that the $1.5^{\circ} \mathrm{C}$ period will be reached by 2027 , which is slightly later than the date of 2025 projected under RCP8.5. Similarly for the MMEM, the RCP4.5 scenario projects that $2^{\circ} \mathrm{C}$ warming will occur by 2048 , nearly 9 years later than under RCP8.5 (2040), similar to previous predictions (Wu et al. 2019; You et al. 2019). The TP is being influenced by global warming 15 years earlier than in seen at the global scale (You et al. 2019).

\section{c. Changes of SWE over the TP}

Figure 3 shows the projected change of regionally averaged spring/winter SWE (relative to 1850-1900) over the TP during 2010-2100 under two RCPs for each CMIP5 model and their MMEM. In both spring and winter, there are large differences between individual models but the biggest percentage decrease is usually in spring. The MMEM of spring/winter SWE over the TP continues to decrease under RCP8.5 until 2100, but the decrease slows after 2050 under RCP4.5, and there is relatively little difference between the two scenarios before 2050 (Fig. 3). Compared with preindustrial levels under RCP8.5 and RCP4.5, the MMEM of spring SWE over the TP is projected to decrease by more than $20 \%$ by the 2050s under both RCPs and under RCP 8.5 the decrease is well in excess of $50 \%$ by 2100 (Fig. 3). The MMEM of spring SWE over the TP decreases around $20.3 \%$ and $20 \%$ under global warming of $1.5^{\circ} \mathrm{C}$ and $26.4 \%$ and $27.9 \%$ under global warming of $2^{\circ} \mathrm{C}$ for RCP8.5 and RCP4.5, respectively (Fig. 4 and Table 3 ). There is relatively little difference in this spatial signature in winter, 
TABLE 3. Relative change of regionally averaged snow water equivalent in spring over the Tibetan Plateau under global warming of $1.5^{\circ}$ and $2^{\circ} \mathrm{C}$ relative to the preindustrial levels (1850-1900 period) under RCP4.5 and RCP8.5 from the 18 CMIP5 models and the multimodel ensemble mean (MMEM) (\%). The changes exceeding the 5\% and $10 \%$ significance level under a $t$ test are indicated by $* *$ and $*$, respectively.

\begin{tabular}{|c|c|c|c|c|c|c|}
\hline \multirow[b]{2}{*}{ Model name } & \multicolumn{3}{|c|}{$\mathrm{RCP} 4.5$} & \multicolumn{3}{|c|}{$\mathrm{RCP} 8.5$} \\
\hline & $1.5^{\circ} \mathrm{C}$ & $2^{\circ} \mathrm{C}$ & $\begin{array}{l}\text { Difference in two } \\
\text { warming scenarios }\end{array}$ & $1.5^{\circ} \mathrm{C}$ & $2^{\circ} \mathrm{C}$ & $\begin{array}{c}\text { Difference in two } \\
\text { warming scenarios }\end{array}$ \\
\hline ACCESS1.0 & $-24.6^{* *}$ & $-39.2 * *$ & $-14.6 * *$ & $-23.6^{* *}$ & $-35.2 * *$ & $-11.6 * *$ \\
\hline BCC_CSM1.1 & $-13.0 * *$ & $-18.8^{* *}$ & $-5.8^{* *}$ & $-13.6^{* *}$ & $-22.5 * *$ & $-8.8^{* *}$ \\
\hline BNU-ESM & $-16.1 *$ & $-14.5^{*}$ & 1.6 & $-24.1^{* *}$ & $-33.2 * *$ & $-9.1 * *$ \\
\hline CanESM2 & -4.6 & $-18.7 * *$ & $-14.1 * *$ & -14.9 & -12.4 & 2.5 \\
\hline CCSM4 & $-27.8 * *$ & $-38.1 * *$ & $-10.3 * *$ & $-29.9 * *$ & $-35.1^{* *}$ & $-5.2 * *$ \\
\hline CESM1(BGC) & $-27.8 * *$ & $-29.9 * *$ & -2.1 & $-31.0 * *$ & $-33.4 * *$ & -2.4 \\
\hline CSIRO-Mk3.6.0 & $-39.4 * *$ & $-34.0 * *$ & $5.4 * *$ & $-28.1 * *$ & $-22.1 * *$ & $6.0 * *$ \\
\hline GFDL CM3 & $-19.8 * *$ & $-39.3 * *$ & $-19.5 * *$ & $-12.7 * *$ & $-32.7 * *$ & $-20.0 * *$ \\
\hline GFDL-ESM2G & $-12.4 * *$ & $-24.0 * *$ & $-11.6 * *$ & $-18.9 * *$ & $-23.2 * *$ & $-4.3^{* *}$ \\
\hline GFDL-ESM2M & $-14.1 * *$ & $-25.6^{* *}$ & $-11.5 * *$ & $-29.6^{* *}$ & $-32.4 * *$ & $-2.8 * *$ \\
\hline INM-CM4 & $-17.4 * *$ & $-31.5^{* *}$ & $-14.2 * *$ & $-19.8^{* *}$ & $-17.0 * *$ & $2.9 * *$ \\
\hline MIROC5 & $-12.0 * *$ & $-27.9 * *$ & $-15.9 * *$ & -5.0 & $-25.6 * *$ & $-20.7 * *$ \\
\hline MIROC-ESM-CHEM & $-19.8 * *$ & $-25.2 * *$ & $-5.5^{* *}$ & $-21.4 * *$ & $-28.3 * *$ & $-6.9 * *$ \\
\hline MIROC-ESM & $-20.6 * *$ & $-25.7 * *$ & $-5.2 * *$ & $-16.5^{* *}$ & $-30.1 * *$ & $-13.5^{* *}$ \\
\hline MPI-ESM-LR & $-26.9 * *$ & $-42.8 * *$ & $-16.0 * *$ & $-18.9 * *$ & $-33.2^{* *}$ & $-14.3 * *$ \\
\hline MPI-ESM-MR & $-22.6 * *$ & $-20.4 * *$ & 2.2 & $-14.8^{* *}$ & $-13.3^{*}$ & 1.6 \\
\hline MRI-CGCM3 & -2.3 & $-15.8^{* *}$ & $-13.6 * *$ & $-11.1^{*}$ & $-11.0^{*}$ & 0.1 \\
\hline NorESM1-M & $-38.3 * *$ & $-30.7 * *$ & $7.6 * *$ & $-31.6^{* *}$ & $-35.0 * *$ & $-3.4^{*}$ \\
\hline MMEM & $-20.0 * *$ & $-27.9 * *$ & $-7.9 * *$ & $-20.3^{* *}$ & $-26.4 * *$ & $-6.1 * *$ \\
\hline
\end{tabular}

but percentage changes in SWE are smaller. The MMEM of winter SWE decreases approximately $13.9 \%$ and $14.5 \%$ under a global warming of $1.5^{\circ} \mathrm{C}$ and $19.7 \%$ and $21.8 \%$ under global warming of $2^{\circ} \mathrm{C}$ for RCP8.5 and RCP4.5, respectively (Fig. 4 and Table 4 ).
The spatial distribution of the MMEM of spring/ winter SWE over the TP under global warming of $1.5^{\circ}$ and $2^{\circ} \mathrm{C}$ relative to $1850-1900$ period shows that the western TP which shows the largest reduction in all cases (Fig. 5), because there are more rapid increases in

TABLE 4. As in Table 3, but for winter.

\begin{tabular}{|c|c|c|c|c|c|c|}
\hline \multirow[b]{2}{*}{ Model name } & \multicolumn{3}{|c|}{$\mathrm{RCP} 4.5$} & \multicolumn{3}{|c|}{ RCP8.5 } \\
\hline & $1.5^{\circ} \mathrm{C}$ & $2^{\circ} \mathrm{C}$ & $\begin{array}{l}\text { Difference in two } \\
\text { warming scenarios }\end{array}$ & $1.5^{\circ} \mathrm{C}$ & $2^{\circ} \mathrm{C}$ & $\begin{array}{l}\text { Difference in two } \\
\text { warming scenarios }\end{array}$ \\
\hline ACCESS1.0 & $-21.4 * *$ & $-30.2 * *$ & $-8.7 * *$ & $-13.8^{*}$ & $-16.9 *$ & -3.1 \\
\hline BCC_CSM1.1 & -6.0 & $-9.8 * *$ & $-3.8 * *$ & -7.5 & $-16.7 * *$ & $-9.2 * *$ \\
\hline BNU-ESM & -5.6 & -7.2 & -1.6 & $-16.3 * *$ & $-20.3 * *$ & -4.0 \\
\hline CanESM2 & 6.9 & $-19.0 * *$ & $-26.0 * *$ & -6.2 & -6.2 & 0.0 \\
\hline CCSM4 & $-20.9 * *$ & $-28.7 * *$ & $-7.7 * *$ & $-19.6^{* *}$ & $-22.4 * *$ & $-2.8 *$ \\
\hline CESM1(BGC) & $-17.5 * *$ & $-17.4 * *$ & 0.1 & $-19.6 * *$ & $-22.2 * *$ & -2.6 \\
\hline CSIRO-Mk3.6.0 & -9.5 & -5.1 & 4.4 & -2.6 & -3.3 & -0.7 \\
\hline GFDL CM3 & $-24.7 * *$ & $-49.8 * *$ & $-25.1 * *$ & $-17.6^{* *}$ & $-43.0 * *$ & $-25.4 * *$ \\
\hline GFDL-ESM2G & $-22.0 * *$ & $-28.5 * *$ & $-6.6 * *$ & $-23.5 * *$ & $-28.0 * *$ & $-4.4 * *$ \\
\hline GFDL-ESM2M & $-20.7 * *$ & $-34.4 * *$ & $-13.7 * *$ & $-33.2 * *$ & $-38.6^{* *}$ & $-5.4 * *$ \\
\hline INM-CM4 & -7.9 & $-25.1 * *$ & $-17.3 * *$ & $-16.6^{* *}$ & -5.8 & $10.7 * *$ \\
\hline MIROC5 & $-8.4^{*}$ & $-22.0 * *$ & $-13.6^{* *}$ & -4.4 & $-21.9 * *$ & $-17.6^{* *}$ \\
\hline MIROC-ESM-CHEM & $-13.9 * *$ & $-20.9 * *$ & $-7.0 * *$ & $-17.9 * *$ & $-22.5 * *$ & $-4.6^{* *}$ \\
\hline MIROC-ESM & $-16.6^{* *}$ & $-21.6^{* *}$ & $-4.9 * *$ & $-12.0 * *$ & $-26.5 * *$ & $-14.5 * *$ \\
\hline MPI-ESM-LR & $-28.8 * *$ & $-38.5 * *$ & $-9.7 * *$ & -13.3 & $-28.2 * *$ & $-14.9 * *$ \\
\hline MPI-ESM-MR & $-19.6 * *$ & $-13.5 * *$ & $6.1 * *$ & -4.3 & -9.1 & $-4.8 *$ \\
\hline MRI-CGCM3 & -2.1 & -3.3 & -1.2 & -7.8 & -6.5 & 1.3 \\
\hline NorESM1-M & $-21.7 * *$ & $-17.7 * *$ & $4.0 * *$ & $-14.3 * *$ & $-16.6^{* *}$ & -2.2 \\
\hline MMEM & $-14.5 * *$ & $-21.8 * *$ & $-7.3 * *$ & $-13.9 * *$ & $-19.7 * *$ & $-5.8 * *$ \\
\hline
\end{tabular}




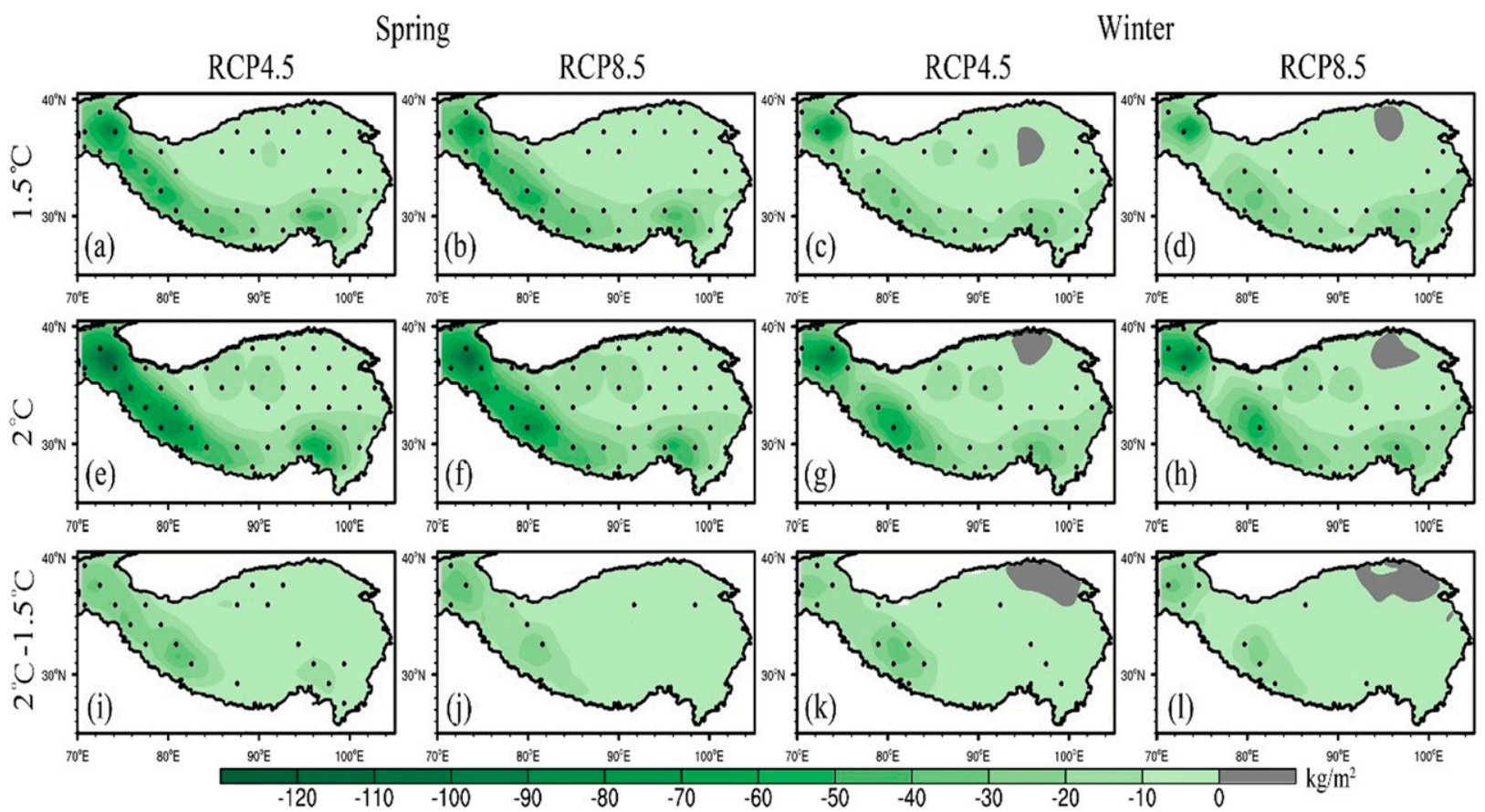

FIG. 5. Spatial distribution of snow water equivalent (SWE) in spring and winter over the Tibetan Plateau from the multimodel ensemble mean (MMEM) of the 18 CMIP5 models under two RCPs under global warming of $1.5^{\circ}$ and $2^{\circ} \mathrm{C}$ above the preindustrial levels (1850-1900 period). These situations under the difference of warming $0.5^{\circ} \mathrm{C}\left(2^{\circ}\right.$ minus $\left.1.5^{\circ} \mathrm{C}\right)$ are also shown. The values with a significance level greater than $5 \%$ are highlighted with the black dot.

temperature modeled in this region probably caused by the snow-albedo feedback between cryosphere and atmosphere (Wu et al. 2019; You et al. 2019). To estimate to what degree regions will become snow free in the future, the spatial distribution of the relative spring/ winter SWE changes over the TP under global warming of $1.5^{\circ}$ and $2^{\circ} \mathrm{C}$ with respect to relative to $1981-2005$ period is shown in Fig. 6 , the negative changes occur over the TP under two RCPs, and the Himalayan region has the largest changes consistent with the severe deglaciation and rapid warming. This is a possible indicator for an upcoming critical tipping point with respect to water supply and total deglaciation over the TP.

For the differences in the MMEM of spring/winter SWE over the TP comparing projected $2^{\circ} \mathrm{C}$ minus projected $1.5^{\circ} \mathrm{C}$ changes (Fig. 5), the regionally averaged

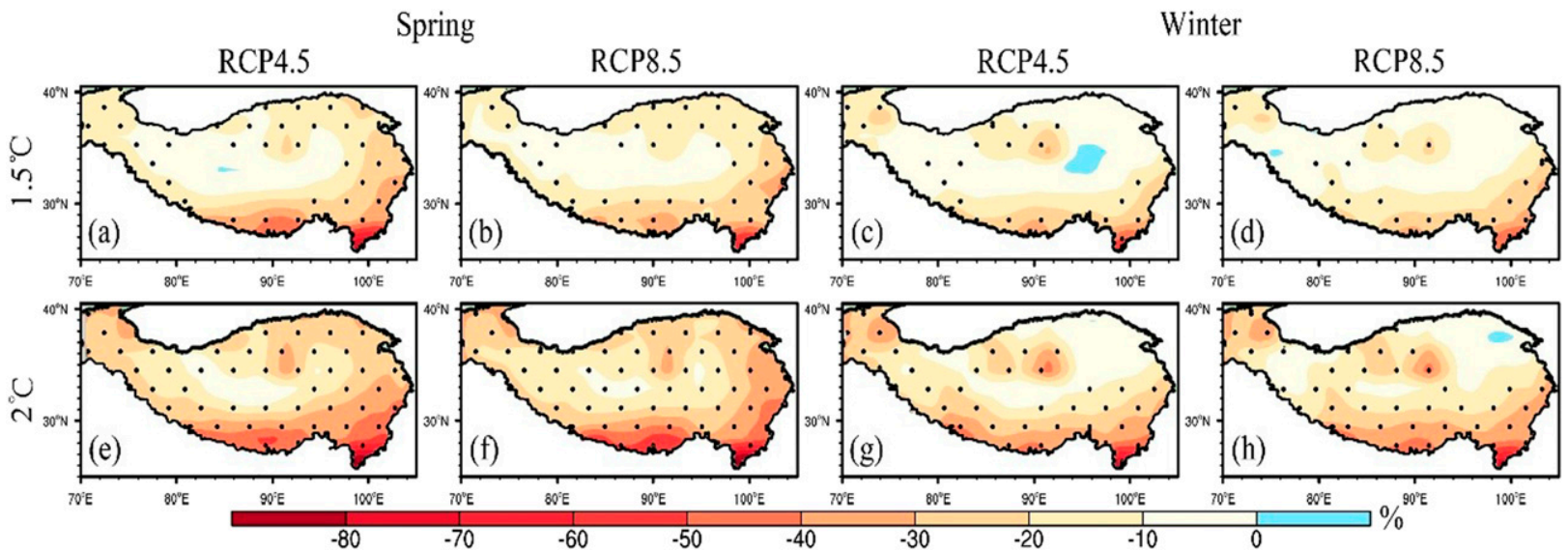

FIG. 6. Spatial distribution of relative changes in spring/winter snow water equivalent (SWE) (relative to 1981-2005 reference period) over the Tibetan Plateau from the multimodel ensemble mean (MMEM) of the 18 CMIP5 models under two RCPs under global warming of (a)-(d) $1.5^{\circ}$ and (e)-(f) $2^{\circ} \mathrm{C}$. The areas exceeding the $5 \%$ significance level under a $t$ test are indicated by dots. 
MMEM of spring/winter SWE for this difference demonstrates the extra snow loss that would be experienced at the higher level of warming. This excess is clear, indicating the enhanced sensitivity of snowpack to warming in this region (You et al. 2019). Compared with preindustrial levels under RCP4.5 (RCP8.5), the extra snow loss for the higher level of warming for the MMEM in spring and winter SWE is $7.9 \%(6.1 \%)$ and $7.3 \%(5.8 \%)$, respectively (Tables 3 and 4$)$. Mountain ranges over western TP such as the Karakorum-Kunlun show the largest differences between the two scenarios, indicating that the reduction of SWE will be spatially variable in response to the extra global warming of $0.5^{\circ} \mathrm{C}$.

\section{d. Elevation dependency of SWE over the TP}

Recent warming has often been elevation dependency both on global and regional scales (Pepin et al. 2015, 2019; You et al. 2016, 2019). Elevation dependency may be exemplified by high warming rates over the TP as a whole (compared with other regions) or manifest as elevational gradients of change within the plateau itself. Figure 7 shows projected relative change of regionally averaged spring/winter SWE relative to preindustrial levels during 2010-2100 over the Northern Hemisphere, China, and the TP. The MMEM of the 18 CMIP5 models shows more rapid reduction in SWE for the TP under RCP 8.5 and RCP4.5 than for China or the whole Northern Hemisphere, indicating that the TP is a sensitive region to climate change.

To investigate elevation dependency within the TP, Fig. 8 shows changes in SWE in spring/winter for different elevation ranges under two RCPs from the MMEM under global warming of $1.5^{\circ}$ and $2^{\circ} \mathrm{C}$. The number of grid cells in each elevation range is listed on the $x$ axis. It is clear that the strongest SWE decline is observed between 4000 and $4500 \mathrm{~m}$ in both spring and winter, with smaller declines above this and much less below this. This suggests that the relationship between the elevation and SWE change is complex, due to multiple controlling factors such as precipitation, temperature, and solar radiation. Other research has shown that a negative correlation between the SWE trend and elevation exists in regions of highest snow-water storage during 1987-2009, indicating that mean SWE is increasing (decreasing) at low (high) elevation (Smith and Bookhagen 2018).

\section{e. Relationship between future SWE changes and temperature over the TP}

Correlation coefficients for annual SWE values relative to the preindustrial (1850-1900) in spring/winter for each CMIP5 model versus those for the MMEM under
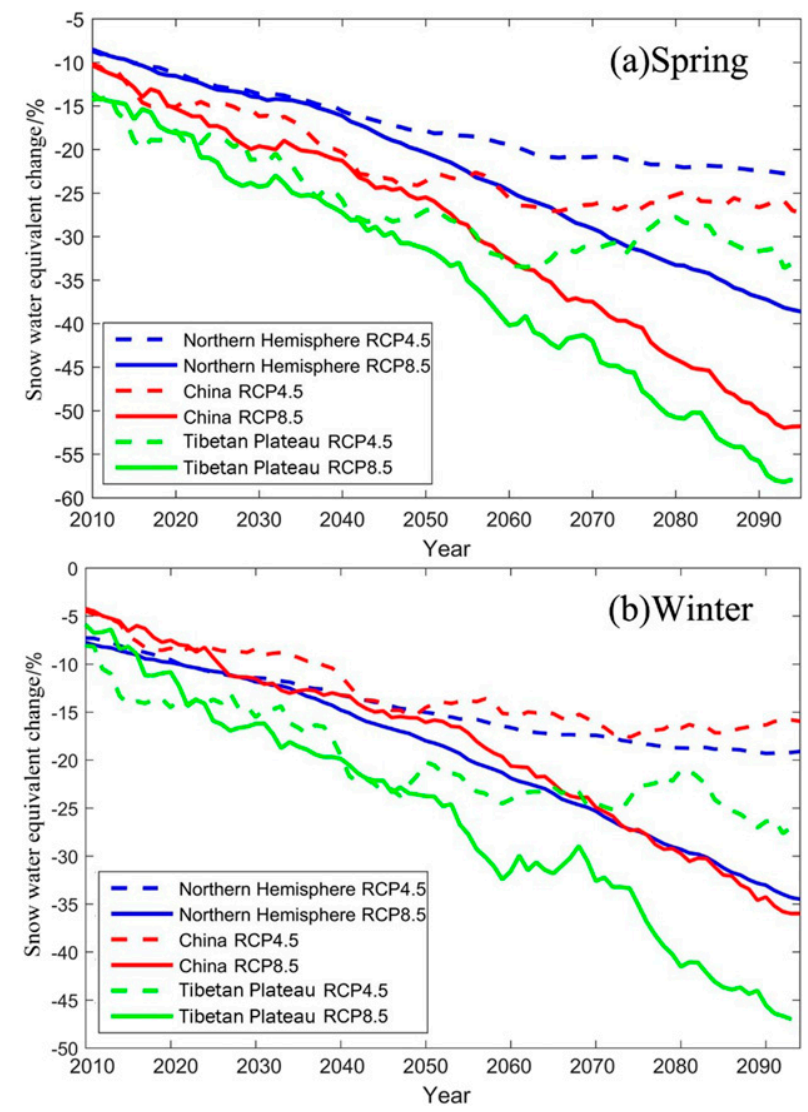

FIG. 7. Projected relative change of regionally averaged snow water equivalent (SWE) relative to the preindustrial levels (18501900 period) in (a) spring and (b) winter during 2010-2100 over the Northern Hemisphere, China, and the Tibetan Plateau under two RCPs from the multimodel ensemble mean (MMEM) of the 18 CMIP5 models. The curve is based on the 9-yr running average.

two RCPs are summarized in Table 5. As shown in Table 5, there are differences between individual models in their predictions of future SWE change. NorESM1-M in particular shows low correlation with the MMEM, particularly under RCP4.5, and CSIRO$\mathrm{Mk3}$.6.0 is an outlier with negative correlations under the same scenario.

Based on the time series of the SWE, mean temperature, maximum temperature, and minimum temperature in spring and winter over the TP during 2010-2100 under two RCPs from the MMEM (Fig. 9), the temperatures under RCP4.5 tend to stabilize around 2080. SWE in spring and winter continues to decrease until 2100 , but there has much interannual variability. For the RCP8.5 scenario there is a more consistent decrease in SWE until 2100 coupled with an increase in all temperatures. Thus the correlations between SWE and temperature tend to be higher under RCP8.5 (Table 6). Significant negative correlations also exist between projected 

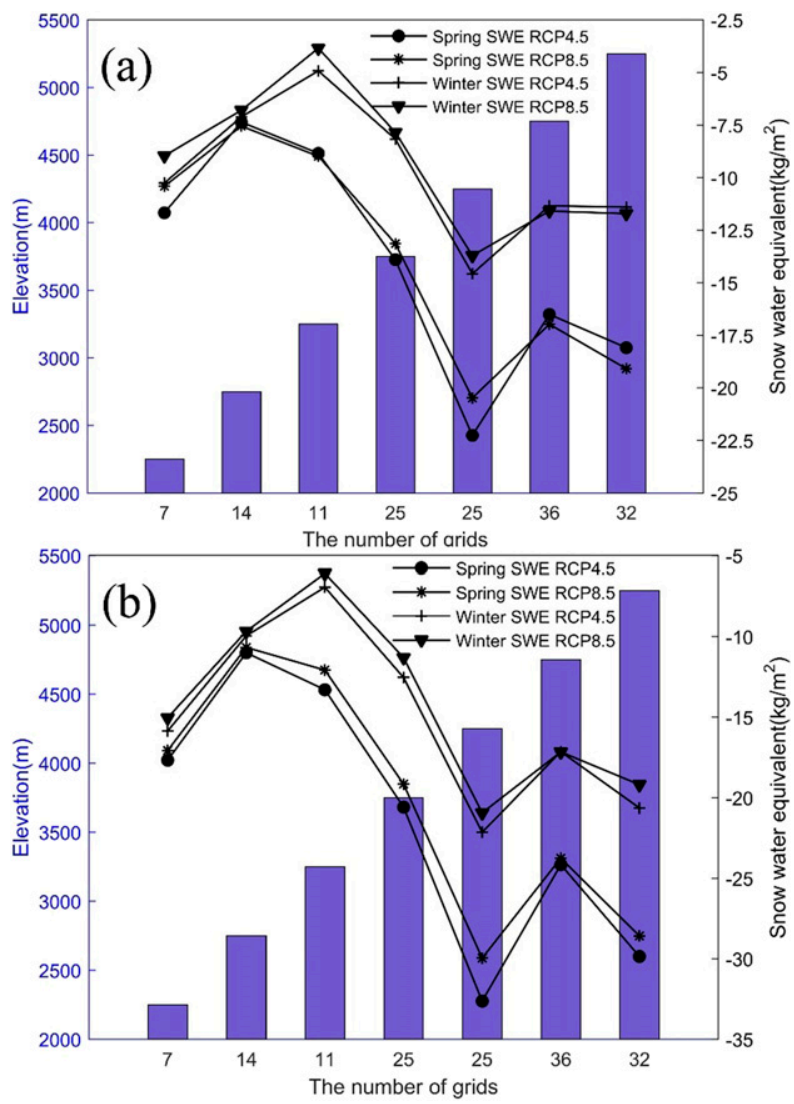

FIG. 8. Snow water equivalent (SWE) in spring and winter in difference elevation ranges over the Tibetan Plateau under two RCPs from the multimodel ensemble mean (MMEM) of the 18 CMIP5 models under global warming of (a) $1.5^{\circ}$ and (b) $2^{\circ} \mathrm{C}$ above the preindustrial levels (1850-1900 period). The number of grids in difference elevation ranges is also shown.

SWE and mean temperature, maximum temperature, and minimum temperature in spring and winter over the TP, and most CMIP5 models are significant. This indicates that SWE over the TP appears to experience a decrease in response to global warming.

The relationship between mean SWE during 18501900 (historical period) and mean SWE under global warming of $1.5^{\circ}$ and $2^{\circ} \mathrm{C}$ in spring/winter over the TP under two RCPs for the 18 CMIP5 models shows that there is a very strong positive relationship between a model's future SWE prediction and its historical mean SWE, indicating that the initial conditions of SWE in each CMIP5 model are a vital control of their future projection (Fig. 10). It should be noted that the initial conditions are simply the values the projection is started with, and the transient boundary conditions (e.g., trace gases) together with the internal dynamics of the system finally determine the projected SWE.
TABLE 5. Correlation coefficient between each CMIP5 model and the multimodel ensemble mean (MMEM) of regionally averaged snow water equivalent during 2010-2100 in spring and winter over the Tibetan Plateau under two RCPs. The correlations exceeding the $5 \%$ significance level under a $t$ test are indicated by $* *$.

\begin{tabular}{|c|c|c|c|c|}
\hline \multirow[b]{2}{*}{ Model name } & \multicolumn{2}{|c|}{ Spring } & \multicolumn{2}{|c|}{ Winter } \\
\hline & $\mathrm{RCP} 4.5$ & RCP8.5 & $\mathrm{RCP} 4.5$ & RCP8.5 \\
\hline ACCESS1.0 & $0.85^{* *}$ & $0.97 * *$ & $0.83 * *$ & $0.97 * *$ \\
\hline BCC_CSM1.1 & $0.68 * *$ & $0.83 * *$ & $0.29 * *$ & $0.78 * *$ \\
\hline BNU-ESM & $0.64 * *$ & $0.93 * *$ & $0.55 * *$ & $0.90 * *$ \\
\hline CanESM2 & $0.77 * *$ & $0.86^{* *}$ & $0.65 * *$ & $0.67 * *$ \\
\hline CCSM4 & $0.35 * *$ & $0.91 * *$ & $0.35 * *$ & $0.73 * *$ \\
\hline CESM1(BGC) & $0.48 * *$ & $0.88 * *$ & $0.48 * *$ & $0.90 * *$ \\
\hline CSIRO-Mk3.6.0 & $-0.49 * *$ & $0.46^{* *}$ & $-0.49 * *$ & $-0.35 * *$ \\
\hline GFDL CM3 & $0.91 * *$ & $0.98 * *$ & $0.93 * *$ & $0.96 * *$ \\
\hline GFDL-ESM2G & $0.79 * *$ & $0.93 * *$ & $0.91 * *$ & $0.92 * *$ \\
\hline GFDL-ESM2M & $0.88 * *$ & $0.91 * *$ & $0.92 * *$ & $0.92 * *$ \\
\hline INM-CM4 & $0.77 * *$ & $0.95^{* *}$ & $0.45^{* *}$ & $0.82 * *$ \\
\hline MIROC5 & $0.91 * *$ & $0.92 * *$ & $0.87 * *$ & $0.91 * *$ \\
\hline MIROC-ESM-CHEM & $0.87 * *$ & $0.98 * *$ & $0.86 * *$ & $0.97 * *$ \\
\hline MIROC-ESM & $0.79 * *$ & $0.97 * *$ & $0.65 * *$ & $0.98 * *$ \\
\hline MPI-ESM-LR & $0.86 * *$ & $0.96 * *$ & $0.65^{* *}$ & $0.94 * *$ \\
\hline MPI-ESM-MR & $0.26 * *$ & $0.93 * *$ & 0.17 & $0.90 * *$ \\
\hline MRI-CGCM3 & $0.46^{* *}$ & $0.80 * *$ & $0.29 * *$ & $0.60 * *$ \\
\hline NorESM1-M & 0.15 & $0.85^{* *}$ & $0.44 * *$ & $0.83^{* *}$ \\
\hline
\end{tabular}

\section{Discussion and conclusions}

In this study, the 18 CMIP5 models are employed to investigate projected changes in SWE in spring/winter over the TP under global warming of $1.5^{\circ}$ and $2^{\circ} \mathrm{C}$ under RCP8.5 and RCP4.5. Compared with the CanSISE (observed) SWE, four CMIP5 models (ACCESS1.0, CSIRO-Mk3.6.0, MPI-ESM-LR, and MPI-ESM-MR) are recognized as relatively good models for predicting SWE over the TP. These are not the same models (CCSM4, MIROC5, MRI-CGCM3, and FGOALS-g2) that were selected as relatively good models for predicting snow cover over the TP (Wei and Dong 2015). This is caused by a large intermodel variability in the time scales extracted from the CMIP5 models (Agarwal and Wettlaufer 2018). Unsurprisingly, our results predict a decrease in mean SWE in both spring and winter under two RCPs over most regions of the TP. The most significant reductions occur over the western TP, consistent with the greater warming in the same region (Wu et al. 2019; You et al. 2019). The MMEM suggests that the magnitude of reductions in SWE is strongly dependent on the future emissions pathway, with negative trends in SWE under two RCPs before the 2050s, but negative (positive) trends in SWE under RCP8.5 (RCP4.5) after the 2050s. The spatial pattern of projected mean SWE change shows a clear west-east gradient with the largest relative reductions over the western TP. Spring SWE shows larger losses than winter 

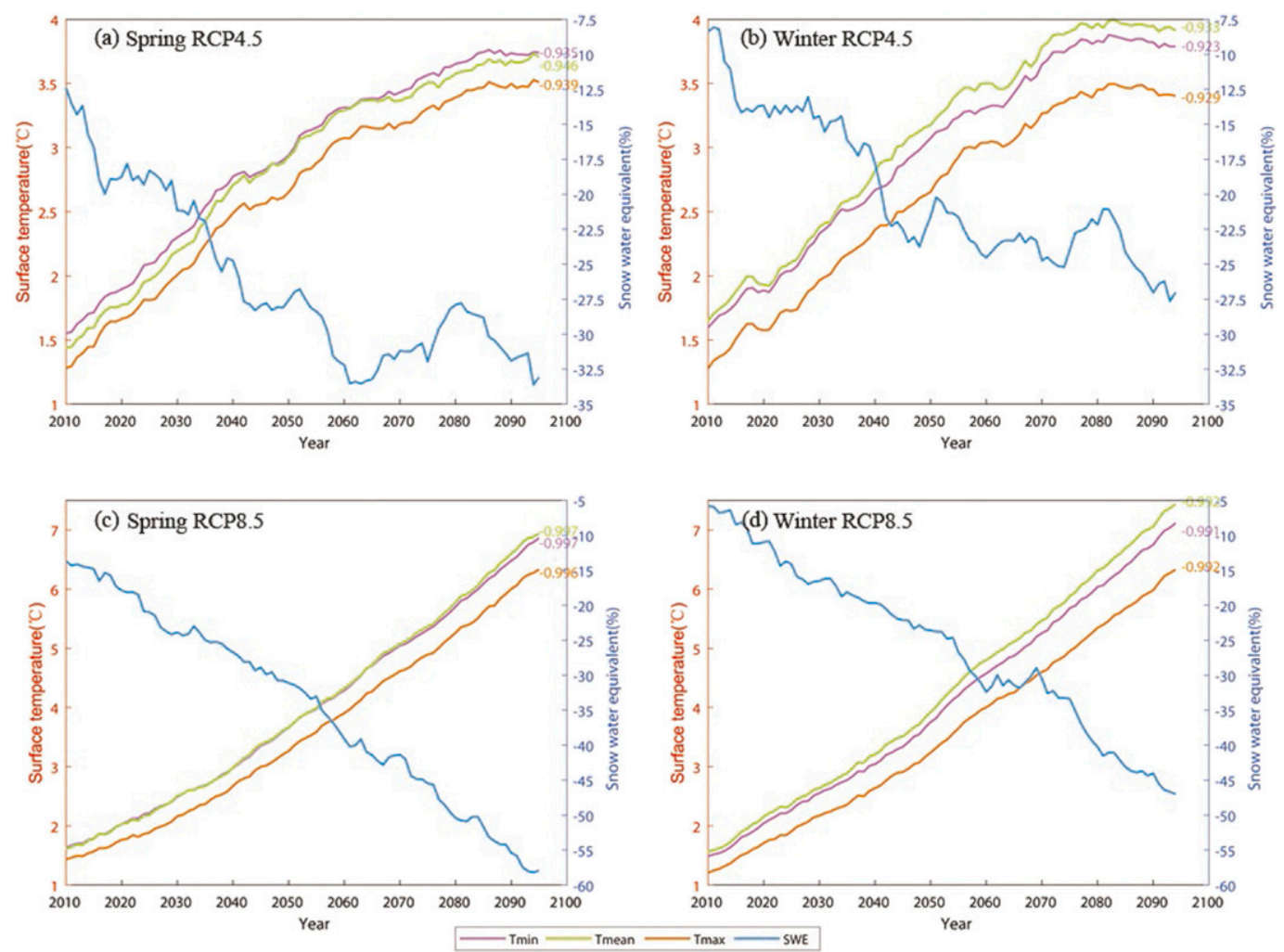

FIG. 9. Time series of snow water equivalent (SWE), mean temperature (Tmean), maximum temperature (Tmax), and minimum temperature (Tmin) in spring and winter over the Tibetan Plateau during 2010-2100 under two RCPs from the multimodel ensemble mean (MMEM) of the 18 CMIP5 models. The curve is based on the 9-yr running average.

SWE. It is recorded that SWE in midwinter over the Northern Hemisphere is expected to increase in highlatitude colder regions because of increased winter snowfall in the future (Maloney et al. 2014) but this does not extend to the TP as a whole in our study.

Compared with the preindustrial period, SWE in spring/winter over the TP under global warming of $1.5^{\circ}$ and $2^{\circ} \mathrm{C}$ will reduce significantly. Moreover, reduction rates are faster than for China as a whole and the Northern Hemisphere, again probably caused by rapid warming over the TP (You et al. 2016, 2019). According to the Fifth Assessment Report of the Intergovernmental Panel on Climate (IPCC 2013), the TP has demonstrated rapid warming within higher elevations, and this elevation dependency is expected to continue in the future (Pepin et al. 2015, 2019; You et al. 2016, 2019). For example, under global warming of $1.5^{\circ}$ and $2^{\circ} \mathrm{C}$ the mean temperature over the TP under RCP4.5 (RCP8.5) will increase by $2.11^{\circ} \mathrm{C}\left(2.10^{\circ} \mathrm{C}\right)$ and $2.89^{\circ} \mathrm{C}\left(2.77^{\circ} \mathrm{C}\right)$, respectively (Wu et al. 2019; You et al. 2019).

The TP is widely recognized to be the driving force for amplification of environmental changes on a regional and global scale (Kang et al. 2010; You et al. 2020). Rapid cryospheric change over the TP is in phase with global trends but is occurring at a higher magnitude (Kang et al. 2019, 2010; Yao et al. 2019, 2020). This is also consistent with previous work that has shown that central Asia will experience warmer and wetter winters

TABLE 6. Correlation coefficient between the snow water equivalent (SWE), mean temperature (Tmean), maximum temperature (Tmax), and minimum temperature (Tmin) of the multimodel ensemble mean (MMEM) of the 18 CMIP5 models in spring and winter over the Tibetan Plateau during 2010-2100 under two RCPs. The changes exceeding the 5\% significance level under a $t$ test are indicated by $* *$.

\begin{tabular}{|c|c|c|c|}
\hline & Tmean (RCP4.5/8.5) & Tmax (RCP4.5/8.5) & $\operatorname{Tmin}(\mathrm{RCP} 4.5 / 8.5)$ \\
\hline Spring SWE & $-0.946 * * /-0.997 * *$ & $-0.939 * * /-0.996 * *$ & $-0.935 * * /-0.997 * *$ \\
\hline Winter SWE & $-0.933 * * /-0.992 * *$ & $-0.929 * * /-0.992 * *$ & $-0.923 * * /-0.991 * *$ \\
\hline
\end{tabular}



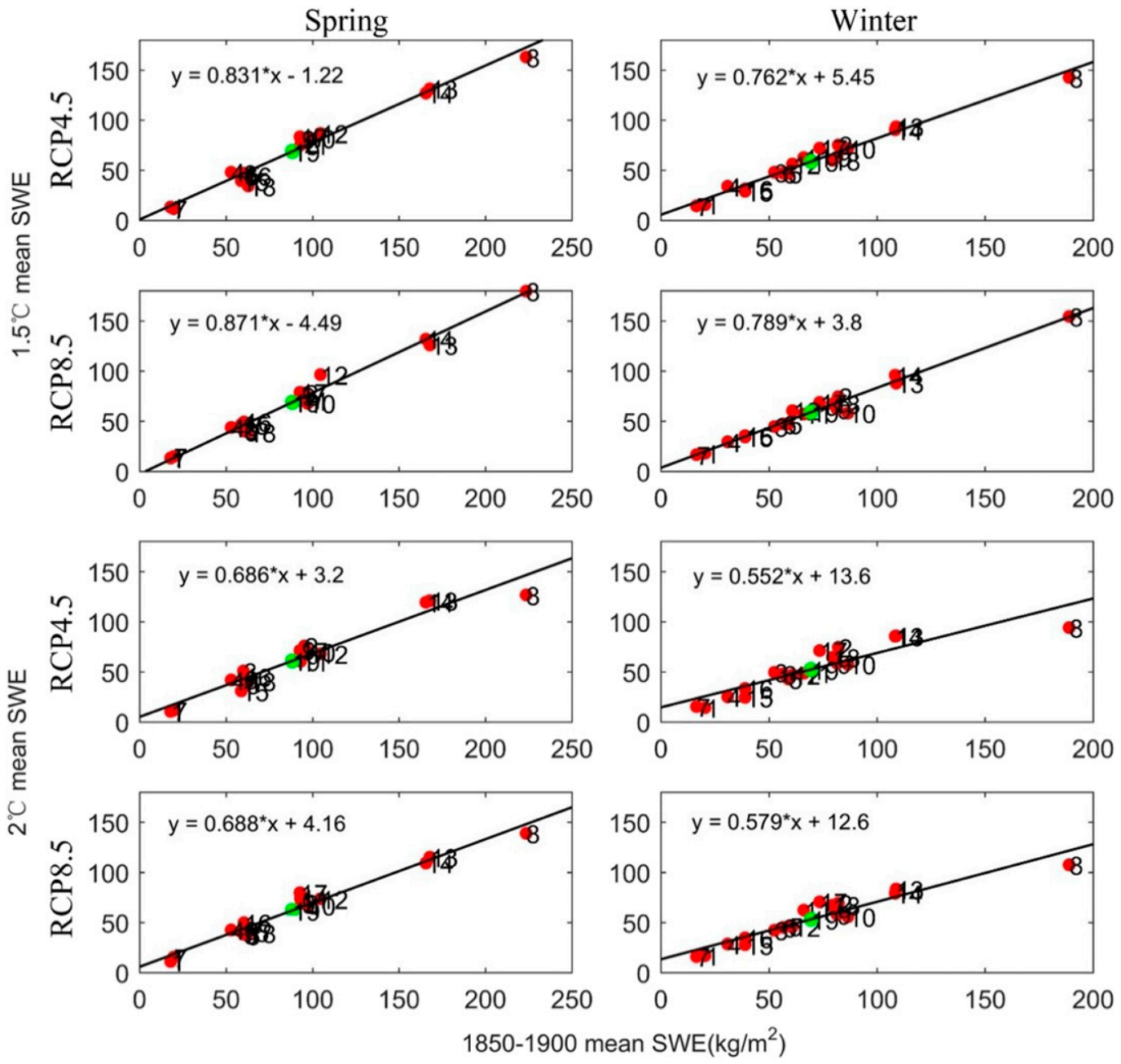

FIG. 10. Relationship between mean snow water equivalent (SWE) during 1850-1900 and mean SWE under global warming of $1.5^{\circ}$ and $2^{\circ} \mathrm{C}$ above the preindustrial levels (1850-1900 period) in spring and winter over the Tibetan Plateau under two RCPs in the 18 CMIP5 models. The numbers 1-18 refer to the model names in Table 1.

under global warming of $1.5^{\circ}$ and $2^{\circ} \mathrm{C}$ ( $\mathrm{Li}$ et al. 2019). Thus, SWE over the TP will continue to decline as a response to rapid warming in the future.

Strong correlations between projected SWE and mean temperature indicate that reduction in SWE can be primarily attributed to increasing temperatures. The SWE-temperature response is also reflected by with the position of the snow line where snow cover is relatively shallow and albedo feedback is large (Brown 2000; Brown and Mote 2009). In addition, an increased ratio of rainfall to snowfall and therefore increased melt efficiency are also important factors contributing to the decrease in SWE over the TP. Since SWE is also dependent on snowfall, influences such as changing moisture sources and atmospheric circulation patterns will also account for SWE change in the future (Deng et al. 2017).
It was found that the future SWE trend does not have a simple elevation dependency, but has maximum projected SWE loss in the elevation band of 4000$4500 \mathrm{~m}$. This is broadly similar to, but perhaps slightly lower than, projections in warming rates over the TP, which are strongest at a slightly higher elevations in most studies, around 4500-5500 m (Gao et al. 2018; Guo et al. 2016; Pepin et al. 2015, 2019; Qin et al. 2009). This suggests that surface albedo feedbacks, cloud, water vapor, and aerosols and their elevation-dependent patterns and so on contributed to the elevation dependency of SWE trends to some extent (Pepin et al. 2015, 2019; You et al. 2016, 2019). There are limited studies on the elevation dependency of SWE trends and more investigation is needed to explore the implications of this phenomenon in the future. 
Acknowledgments. This study is supported by National Key R\&D Program of China (2017YFA0603804) and National Natural Science Foundation of China (41771069 and 41971072). Fudan University-Tibet University Joint Laboratory for Biodiversity and Global Change is acknowledged. We are very grateful to the reviewers for their constructive comments and thoughtful suggestions.

\section{REFERENCES}

Agarwal, S., and J. S. Wettlaufer, 2018: Fluctuations in Arctic seaice extent: Comparing observations and climate models. Philos. Trans. Royal Soc. London, A376, 20170332, https:// doi.org/10.1098/rsta.2017.0332.

Bamzai, A. S., and J. Shukla, 1999: Relation between Eurasian snow cover, snow depth, and the Indian summer monsoon: An observational study. J. Climate, 12, 3117-3132, https://doi.org/ 10.1175/1520-0442(1999)012<3117:RBESCS $>2.0 . C O ; 2$.

Barnett, T. P., L. Dümenil, U. Schlese, E. Roeckner, and M. Latif, 1989: The effect of Eurasian snow cover on regional and global climate variations. J. Atmos. Sci., 46, 661686, https://doi.org/10.1175/1520-0469(1989)046<0661:TEOESC > 2.0.CO;2.

Beniston, M., and Coauthors, 2018: The European mountain cryosphere: A review of its current state, trends, and future challenges. Cryosphere, 12, 759-794, https://doi.org/10.5194/ tc-12-759-2018.

Brown, R. D., 2000: Northern Hemisphere snow cover variability and change, 1915-97. J. Climate, 13, 2339-2355, https://doi.org/ 10.1175/1520-0442(2000)013<2339:NHSCVA>2.0.CO;2.

— constructed Canadian snow cover, 1915-1992. J. Climate, 9, 1299-1318, https://doi.org/10.1175/1520-0442(1996)009<1299: IVIRCS $>2.0 . \mathrm{CO} ; 2$.

, and N. Petkova, 2007: Snow cover variability in Bulgarian mountainous regions, 1931-2000. Int. J. Climatol., 27, 12151229, https://doi.org/10.1002/joc.1468.

- and P. W. Mote, 2009: The response of Northern Hemisphere snow cover to a changing climate. J. Climate, 22, 2124-2145, https://doi.org/10.1175/2008JCLI2665.1.

— , and C. Derksen, 2013: Is Eurasian October snow cover extent increasing? Environ. Res. Lett., 8, 024006, https://doi.org/ 10.1088/1748-9326/8/2/024006.

Brun, E., V. Vionnet, A. Boone, B. Decharme, Y. Peings, R. Valette, F. Karbou, and S. Morin, 2013: Simulation of northern Eurasian local snow depth, mass, and density using a detailed snowpack model and meteorological reanalyses. J. Hydrometeor., 14, 203-219, https://doi.org/10.1175/JHM-D12-012.1.

Bulygina, O. N., P. Y. Groisman, V. N. Razuvaev, and N. N. Korshunova, 2011: Changes in snow cover characteristics over northern Eurasia since 1966. Environ. Res. Lett., 6, 045204, https://doi.org/10.1088/1748-9326/6/4/045204.

Chen, X. N., S. Liang, Y. Cao, and T. He, 2016: Distribution, attribution, and radiative forcing of snow cover changes over China from 1982 to 2013. Climatic Change, 137, 363-377, https://doi.org/10.1007/s10584-016-1688-z.

Dawson, N., P. Broxton, and X. Zeng, 2018: Evaluation of remotely sensed snow water equivalent and snow cover extent over the contiguous United States. J. Hydrometeor., 19, 1777-1791, https://doi.org/10.1175/JHM-D-18-0007.1.
Dee, D. P., and Coauthors, 2011: The ERA-Interim reanalysis: Configuration and performance of the data assimilation system. Quart. J. Roy. Meteor. Soc., 137, 553-597, https://doi.org/ 10.1002/qj.828.

Deng, H., N. C. Pepin, and Y. Chen, 2017: Changes of snowfall under warming in the Tibetan Plateau. J. Geophys. Res Atmos., 122, 7323-7341, https://doi.org/10.1002/2017JD026524.

Dye, D. G., 2002: Variability and trends in the annual snow-cover cycle in Northern Hemisphere land areas, 1972-2000. Hydrol. Processes, 16, 3065-3077, https://doi.org/10.1002/hyp.1089.

Gao, Y., F. Chen, D. P. Lettenmaier, J. Xu, L. Xiao, and X. Li, 2018: Does elevation-dependent warming hold true above $5000 \mathrm{~m}$ elevation? Lessons from the Tibetan Plateau. $n p j$ Climate Atmos. Sci., 1, 19, https://doi.org/10.1038/s41612-0180030-z.

Ge, Y., and G. Gong, 2009: North American snow depth and climate teleconnection patterns. J. Climate, 22, 217-233, https:// doi.org/10.1175/2008JCLI2124.1.

Groisman, P., T. R. Karl, R. W. Knight, and G. L. Stenchikov, 1994: Changes of snow cover, temperature, and radiative heat balance over the Northern Hemisphere. J. Climate, 7, 1633-1656, https://doi.org/10.1175/1520-0442(1994)007<1633:COSCTA $>2$ $0 . \mathrm{CO} ; 2$.

Guo, D., E. Yu, and H. Wang, 2016: Will the Tibetan Plateau warming depend on elevation in the future? J. Geophys. Res. Atmos., 121, 3969-3978, https://doi.org/10.1002/2016JD024871.

Hancock, S., R. Baxter, J. Evans, and B. Huntley, 2013: Evaluating global snow water equivalent products for testing land surface models. Remote Sens. Environ., 128, 107-117, https://doi.org/ 10.1016/j.rse.2012.10.004.

Hernández-Henríquez, M. A., S. J. Déry, and C. Derksen, 2015: Polar amplification and elevation-dependence in trends of Northern Hemisphere snow cover extent, 1971-2014. Environ. Res. Lett., 10, 044010, https://doi.org/10.1088/1748-9326/10/4/ 044010.

IPCC, 2013: Summary for policymakers. Climate Change 2013: The Physical Science Basis, T. F. Stocker et al., Eds., Cambridge University Press, 3-29.

Jeong, D. I., L. Sushama, and M. Naveed Khaliq, 2017: Attribution of spring snow water equivalent (SWE) changes over the Northern Hemisphere to anthropogenic effects. Climate Dyn., 48, 3645-3658, https://doi.org/10.1007/s00382-0163291-4.

Ji, Z., and S. Kang, 2013: Projection of snow cover changes over China under RCP scenarios. Climate Dyn., 41, 589-600, https://doi.org/10.1007/s00382-012-1473-2.

Kang, S. C., Y. W. Xu, Q. L. You, W. A. Flugel, N. Pepin, and T. D. Yao, 2010: Review of climate and cryospheric change in the Tibetan Plateau. Environ. Res. Lett., 5, 015101, https://doi.org/ 10.1088/1748-9326/5/1/015101.

_ , and Coauthors, 2019: Linking atmospheric pollution to cryospheric change in the Third Pole region: Current progress and future prospects. Natl. Sci. Rev., 6, 796-809, https:// doi.org/10.1093/nsr/nwz031.

Ke, C. Q., and X. Liu, 2014: MODIS-observed spatial and temporal variation in snow cover in Xinjiang, China. Climate Res., 59, 15-26, https://doi.org/10.3354/cr01206.

King, A. D., D. J. Karoly, and B. J. Henley, 2017: Australian climate extremes at $1.5^{\circ} \mathrm{C}$ and $2^{\circ} \mathrm{C}$ of global warming. Nat. Climate Change, 7, 412-416, https://doi.org/10.1038/nclimate3296.

Kong, Y., and C.-H. Wang, 2017: Responses and changes in the permafrost and snow water equivalent in the Northern Hemisphere under a scenario of $1.5^{\circ} \mathrm{C}$ warming. $A d v$. 
Climate Change Res., 8, 235-244, https://doi.org/10.1016/ j.accre.2017.07.002.

Laternser, M., and M. Schneebeli, 2003: Long-term snow climate trends of the Swiss Alps (1931-99). Int. J. Climatol., 23, 733750, https://doi.org/10.1002/joc.912.

Li, C., F. Su, D. Yang, K. Tong, F. Meng, and B. Kan, 2018: Spatiotemporal variation of snow cover over the Tibetan Plateau based on MODIS snow product, 2001-2014. Int. J. Climatol., 38, 708-728, https://doi.org/10.1002/joc.5204.

Li, Y., H. Tao, B. Su, Z. W. Kundzewicz, and T. Jiang, 2019: Impacts of $1.5^{\circ} \mathrm{C}$ and $2^{\circ} \mathrm{C}$ global warming on winter snow depth in Central Asia. Sci. Total Environ., 651, 2866-2873, https://doi.org/10.1016/j.scitotenv.2018.10.126.

Maloney, E. D., and Coauthors, 2014: North American climate in CMIP5 experiments: Part III: Assessment of twenty-firstcentury projections. J. Climate, 27, 2230-2270, https://doi.org/ 10.1175/JCLI-D-13-00273.1.

Moss, R. H., and Coauthors, 2010: The next generation of scenarios for climate change research and assessment. Nature, $\mathbf{4 6 3}, 747$ 756, https://doi.org/10.1038/nature08823.

Mote, P. W., A. F. Hamlet, M. P. Clark, and D. P. Lettenmaier, 2005: Declining mountain snowpack in western North America. Bull. Amer. Meteor. Soc., 86, 39-50, https://doi.org/ 10.1175/BAMS-86-1-39.

Mudryk, L. R., and C. Derksen, 2017: CanSISE Observation-Based Ensemble of Northern Hemisphere Terrestrial Snow Water Equivalent, Version 2. National Snow and Ice Data Center, https://doi.org/10.5067/96ltniikJ7vd.

,-- , P. J. Kushner, and R. Brown, 2015: Characterization of Northern Hemisphere snow water equivalent datasets, 19812010. J. Climate, 28, 8037-8051, https://doi.org/10.1175/JCLID-15-0229.1.

Pepin, N. C., and Coauthors, 2015: Elevation-dependent warming in mountain regions of the world. Nat. Climate Change, 5, 424430, https://doi.org/10.1038/nclimate2563.

- - H. Deng, H. Zhang, F. Zhang, S. Kang, and T. Yao, 2019: An examination of temperature trends at high elevations across the Tibetan Plateau: The use of MODIS LST to understand patterns of elevation-dependent warming. J. Geophys. Res. Atmos., 124, 5738-5756, https://doi.org/10.1029/ 2018JD029798

Qin, D. H., S. Y. Liu, and P. J. Li, 2006: Snow cover distribution, variability, and response to climate change in western China. J. Climate, 19, 1820-1833, https://doi.org/10.1175/ JCLI3694.1.

Qin, J., K. Yang, S. L. Liang, and X. F. Guo, 2009: The altitudinal dependence of recent rapid warming over the Tibetan Plateau. Climatic Change, 97, 321-327, https://doi.org/10.1007/s10584009-9733-9.

Räisänen, J., 2008: Warmer climate: Less or more snow? Climate Dyn., 30, 307-319, https://doi.org/10.1007/s00382007-0289-y.

— northern Europe: A high-resolution view from ENSEMBLES regional climate models. Climate Dyn., 38, 2575-2591, https:// doi.org/10.1007/s00382-011-1076-3.

Rienecker, M. M., and Coauthors, 2011: MERRA: NASA's Modern-Era Retrospective Analysis for Research and Applications. J. Climate, 24, 3624-3648, https://doi.org/10.1175/ JCLI-D-11-00015.1.

Rodell, M., and Coauthors, 2004: The Global Land Data Assimilation System. Bull. Amer. Meteor. Soc., 85, 381-394, https://doi.org/10.1175/BAMS-85-3-381.
Shi, H. X., and C. H. Wang, 2015: Projected 21st century changes in snow water equivalent over Northern Hemisphere landmasses from the CMIP5 model ensemble. Cryosphere, 9, 1943-1953, https://doi.org/10.5194/tc-9-1943-2015.

Shi, X., P. Y. Groisman, S. J. Déry, and D. P. Lettenmaier, 2011: The role of surface energy fluxes in pan-Arctic snow cover changes. Environ. Res. Lett., 6, 035204, https://doi.org/10.1088/ 1748-9326/6/3/035204.

Smith, T., and B. Bookhagen, 2018: Changes in seasonal snow water equivalent distribution in High Mountain Asia (1987 to 2009). Sci. Adv., 4, e1701550, https://doi.org/10.1126/ sciadv. 1701550 .

Snauffer, A. M., W. W. Hsieh, and A. J. Cannon, 2016: Comparison of gridded snow water equivalent products with in situ measurements in British Columbia, Canada. J. Hydrol., 541, 714726, https://doi.org/10.1016/j.jhydrol.2016.07.027.

Takala, M., K. Luojus, J. Pulliainen, C. Derksen, J. Lemmetyinen, J.-P. Kärnä, J. Koskinen, and B. Bojkov, 2011: Estimating Northern Hemisphere snow water equivalent for climate research through assimilation of space-borne radiometer data and ground-based measurements. Remote Sens. Environ., 115, 3517-3529, https://doi.org/10.1016/j.rse.2011.08.014.

Tan, X., W. Zhenni, M. Xingmin, G. Peng, Z. Guangju, S. Wenyi, and G. Chaojun, 2019: Spatiotemporal changes in snow cover over China during 1960-2013. Atmos. Res., 218, 183-194, https://doi.org/10.1016/j.atmosres.2018.11.018.

Taylor, K. E., 2001: Summarizing multiple aspects of model performance in a single diagram. J. Geophys. Res., 106, 71837192, https://doi.org/10.1029/2000JD900719.

, R. J. Stouffer, and G. A. Meehl, 2012: An overview of CMIP5 and the experiment design. Bull. Amer. Meteor. Soc., 93, 485498, https://doi.org/10.1175/BAMS-D-11-00094.1.

Wang, A., L. Xu, and X. Kong, 2018: Assessments of the Northern Hemisphere snow cover response to 1.5 and $2.0^{\circ} \mathrm{C}$ warming. Earth Syst. Dyn., 9, 865-877, https://doi.org/10.5194/esd-9-8652018.

Wei, Z. G., and W. J. Dong, 2015: Assessment of simulations of snow depth in the Qinghai-Tibetan Plateau using CMIP5 multi-models. Arct. Antarct. Alp. Res., 47, 611-625, https:// doi.org/10.1657/AAAR0014-050.

Wu, F., Q. L. You, W. X. Xie, and L. Zhang, 2019: Temperature change on the Tibetan Plateau under the global warming of $1.5^{\circ} \mathrm{C}$ and $2^{\circ} \mathrm{C}$ (in Chinese). Climate Change Res., 15, $130-139$.

Xu, W., L. Ma, M. Ma, H. Zhang, and W. Yuan, 2017: Spatialtemporal variability of snow cover and depth in the QinghaiTibetan Plateau. J. Climate, 30, 1521-1533, https://doi.org/ 10.1175/JCLI-D-15-0732.1.

Yang, M., X. Wang, G. Pang, G. Wan, and Z. Liu, 2019: The Tibetan Plateau cryosphere: Observations and model simulations for current status and recent changes. Earth-Sci. Rev., 190, 353-369, https://doi.org/10.1016/j.earscirev.2018.12.018.

Yao, T. D., and Coauthors, 2019: Recent Third Pole's rapid warming accompanies cryospheric melt and water cycle intensification and interactions between monsoon and environment: Multi-disciplinary approach with observation, modeling and analysis. Bull. Amer. Meteor. Soc., 100, 423-444, https:// doi.org/10.1175/BAMS-D-17-0057.1.

You, Q. L., S. C. Kang, G. Y. Ren, K. Fraedrich, N. Pepin, Y. P. Yan, and L. J. Ma, 2011: Observed changes in snow depth and number of snow days in the eastern and central Tibetan Plateau. Climate Res., 46, 171-183, https://doi.org/10.3354/ cr00985. 
_ J. Min, and S. Kang, 2016: Rapid warming in the Tibetan Plateau from observations and CMIP5 models in recent decades. Int. J. Climatol., 36, 2660-2670, https://doi.org/ 10.1002/joc. 4520 .

—, Y. Q. Zhang, X. Xie, and F. Wu, 2019: Robust elevation dependency warming over the Tibetan Plateau under global warming of $1.5^{\circ} \mathrm{C}$ and $2^{\circ} \mathrm{C}$. Climate Dyn., 53, 2047-2060, https://doi.org/10.1007/s00382-019-04775-4.

— the Tibetan Plateau and its influence on the broad climate system. Earth-Sci. Rev., 201, 103043, https://doi.org/10.1016/ j.earscirev.2019.103043.

Zeng, X., P. Broxton, and N. Dawson, 2018: Snowpack change from 1982 to 2016 over conterminous United States. Geophys. Res. Lett., 45, 12 940-12 947, https://doi.org/10.1029/2018GL079621.

Zhang, T., 2005: Influence of the seasonal snow cover on the ground thermal regime: An overview. Rev. Geophys., 43, RG4002, https://doi.org/10.1029/2004RG000157.

Zhang, Yinsheng, and N. Ma, 2018: Spatiotemporal variability of snow cover and snow water equivalent in the last three decades over Eurasia. J. Hydrol., 559, 238-251, https://doi.org/ 10.1016/j.jhydrol.2018.02.031.

Zhang, Yongsheng, T. Li, and B. Wang, 2004: Decadal change of the spring snow depth over the Tibetan Plateau: The associated circulation and influence on the East Asian summer monsoon. J. Climate, 17, 2780-2793, https://doi.org/10.1175/ 1520-0442(2004)017<2780:DCOTSS > 2.0.CO;2.

Zhang, Y. Q., Q. You, G. Mao, C. Chen, and Z. Ye, 2019: Shortterm concurrent drought and heatwave frequency with 1.5 and $2.0^{\circ} \mathrm{C}$ global warming in humid subtropical basins: A case study in the Gan River Basin, China. Climate Dyn., 52, 46214641, https://doi.org/10.1007/s00382-018-4398-6.

Zhao, H., and G. W. K. Moore, 2004: On the relationship between Tibetan snow cover, the Tibetan Plateau monsoon and the Indian summer monsoon. Geophys. Res. Lett., 31, L14204, https://doi.org/10.1029/2004GL020040.

Zhong, X., T. Zhang, S. Kang, K. Wang, L. Zheng, Y. Hu, and H. Wang, 2018: Spatiotemporal variability of snow depth across the Eurasian continent from 1966 to 2012. Cryosphere, 12, 227-245, https://doi.org/10.5194/tc-12-227-2018. 